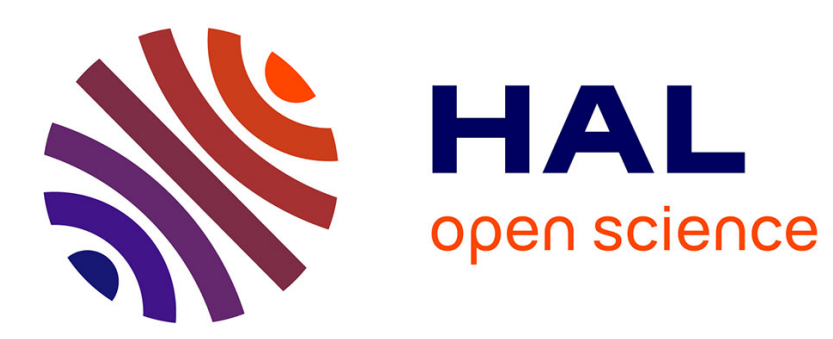

\title{
Visual parameters of chloride-induced corrosion of reinforced concrete structures
}

\author{
Sébastien Charles, Valérie L'Hostis, Stéphane Poyet
}

\section{To cite this version:}

Sébastien Charles, Valérie L'Hostis, Stéphane Poyet. Visual parameters of chloride-induced corrosion of reinforced concrete structures. European Journal of Environmental and Civil Engineering, 2011, 15

(1), pp.9-24. cea-03293535

\section{HAL Id: cea-03293535 \\ https://hal-cea.archives-ouvertes.fr/cea-03293535}

Submitted on 21 Jul 2021

HAL is a multi-disciplinary open access archive for the deposit and dissemination of scientific research documents, whether they are published or not. The documents may come from teaching and research institutions in France or abroad, or from public or private research centers.
L'archive ouverte pluridisciplinaire HAL, est destinée au dépôt et à la diffusion de documents scientifiques de niveau recherche, publiés ou non, émanant des établissements d'enseignement et de recherche français ou étrangers, des laboratoires publics ou privés. 
This article was downloaded by: [CEA Saclay]

On: 29 January 2015, At: 00:56

Publisher: Taylor \& Francis

Informa Ltd Registered in England and Wales Registered Number: 1072954 Registered office: Mortimer House, 37-41 Mortimer Street, London W1T 3J H, UK

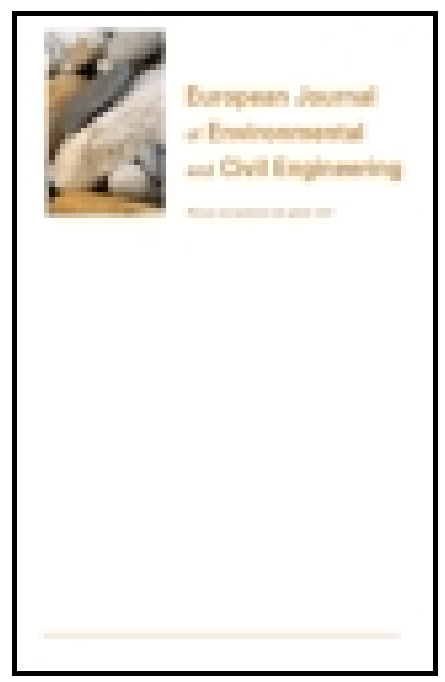

\title{
European J ournal of Environmental and Civil Engineering
}

Publication details, including instructions for authors and subscription information: http:// www. tandfonline.com/loi/tece20

\section{Visual parameters of chloride-induced corrosion of reinforced concrete structures}

\author{
Sébastien Charles ${ }^{a}$, Valérie L'Hostis ${ }^{a} \&$ Stéphane Poyet ${ }^{a}$ \\ ${ }^{a}$ CEA, DEN, DPC, SCCME, Laboratoire d'Etude du Comportement des Bétons et des \\ Argiles, F-91191, Gif-sur-Yvette \\ Published online: 04 Oct 2011.
}

To cite this article: Sébastien Charles, Valérie L'Hostis \& Stéphane Poyet (2011) Visual parameters of chloride-induced corrosion of reinforced concrete structures, European J ournal of Environmental and Civil Engineering, 15:1, 9-24, DOI: 10.1080/19648189.2011.9693304

To link to this article: http:// dx. doi. org/ 10.1080/ 19648189.2011.9693304

\section{PLEASE SCROLL DOWN FOR ARTICLE}

Taylor \& Francis makes every effort to ensure the accuracy of all the information (the "Content") contained in the publications on our platform. However, Taylor \& Francis, our agents, and our licensors make no representations or warranties whatsoever as to the accuracy, completeness, or suitability for any purpose of the Content. Any opinions and views expressed in this publication are the opinions and views of the authors, and are not the views of or endorsed by Taylor \& Francis. The accuracy of the Content should not be relied upon and should be independently verified with primary sources of information. Taylor and Francis shall not be liable for any losses, actions, claims, proceedings, demands, costs, expenses, damages, and other liabilities whatsoever or howsoever caused arising directly or indirectly in connection with, in relation to or arising out of the use of the Content.

This article may be used for research, teaching, and private study purposes. Any substantial or systematic reproduction, redistribution, reselling, loan, sub-licensing, systematic supply, or distribution in any form to anyone is expressly forbidden. Terms \& Conditions of access and use can be found at http:// www.tandfonline.com/page/terms-and-conditions 


\title{
Visual parameters of chloride-induced corrosion of reinforced concrete structures
}

\author{
Sébastien Charles — Valérie L'Hostis — Stéphane Poyet
}

\author{
CEA, DEN, DPC, SCCME \\ Laboratoire d'Etude du Comportement des Bétons et des Argiles \\ F-91191 Gif-sur-Yvette
}

ABSTRACT. Corrosion is the major cause of reinforced concrete structures degradation: the pressure generated by oxides formation together with section loss can eventually lead to cracking and the fall in the structure bearing capacity and then jeopardize its service life. The first method for the corrosion state characterisation of concrete structures is to check periodically for visual signs of corrosion on the concrete facing (rust stains and cracks). The goal of this study is to assess the ability of visual inspection to detect and quantify reinforcement corrosion in concrete structures. The data acquired in the framework of the "Poutres de la Rance" benchmark were re-analysed to link the visual signs of corrosion to its real internal consequences (section loss, corroded length... etc.). The results show that, in our case (marine environment), visual inspection does not yield efficient assessment of the real corrosion state and that other non-destructive techniques must be used in order to gain confidence in the diagnosis.

RÉSUMÉ. La corrosion des armatures est la principale cause de dégradation des ouvrages en béton armé: la pression générée par la formation d'oxydes ainsi que la réduction des sections d'acier peuvent entraîner de la fissuration, la baisse de la capacité portante de la structure et ainsi remettre en cause le service de l'ouvrage. La première technique de contrôle des ouvrages est le relevé régulier des signes apparents de corrosion sur ses parements (tâches et fissures). Le but de cette étude est d'apporter des éléments objectifs permettant d'évaluer la capacité de ce contrôle à détecter et quantifier la corrosion des armatures dans une structure en béton armé. Pour cela, on a réinterprété les données acquises dans le cadre du "Benchmark des poutres de la Rance» pour relier les signes extérieurs de corrosion à ses symptômes internes (pertes de section, longueur corrodée, etc.) Les résultats de cette étude montrent que dans ce cas (environnement marin) le contrôle visuel ne permet pas d'évaluer efficacement l'état de corrosion réel de la structure et doit impérativement être complété par d'autres techniques non destructives pour augmenter le niveau de confiance du diagnostic.

KEYWORDS: reinforced concrete, corrosion, visual inspection, marine environment.

MOTS-CLÉS : béton armé, corrosion, examen visuel, environnement marin.

DOI:10.3166/EJECE.15.9-24 @ 2011 Lavoisier, Paris

EJECE. Volume 15 - No. 1/2011, pages 9 to 24 


\section{Introduction}

In the context of civil engineering, rebar corrosion is a major cause of damage and early failure of reinforced concrete structures. It is consequently recognized as a key issue for ageing concrete structures. Initially, reinforcing steel embedded in concrete is naturally protected from corrosion by a thin oxide film at the surface of the steel. This protective film is stable due to the high alkalinity of the interstitial solution of concrete (L'Hostis et al., 2009). However, this passive film can be destroyed by chemical mechanisms such as chlorides ingress or carbonation. As far as chloride is concerned, localized corrosion leads mainly to steel section losses (Poupard et al., 2006) and transport of rust ("green rust", Raharinaivo et al., 1987) within concrete. Expansive growth of corrosion products can eventually lead to concrete cracking (Tuuti, 1982). As a consequence, visual signs of chloride-inducedcorrosion mainly consist in cracking and rust stains on concrete external face.

In order to estimate the service life of damaged concrete structures, several authors (El Maaddawy et al., 2003; Vidal et al., 2004; Alonso et al., 1998) tried to link visual signs of corrosion (cracks widths) to the real rebar corrosion state (section loss or mass loss). In the case of El Maaddawy et al. and Alonso et al., accelerated tests by using current impressing where used, whereas Vidal et al. studied chloride induced corrosion in simulated marine conditions. Observation of visual signs of corrosion, such as cracks and rust stains, should permit to detect rebar corrosion and it constitutes also an easy and cheap method for the owner compared to electrochemical techniques such as potential mapping and corrosion rate measurements.

Results obtained by El Maaddawy et al. (2003) (Figure 1) show that the concrete crack width increases with the steel section loss. In this study, reinforced concrete prisms were cast 5\% sodium chloride (by weight of cement) dissolved in mixing water. To accelerate corrosion an electric field (between 100 and $500 \mu \mathrm{A} / \mathrm{cm}^{2}$ ) was imposed to reinforcement. Rebar diameter loss was estimated using weight loss measurements.

In the experiments of Alonso et al. (1998), reinforced concrete beams were cast with water containing $3 \%$ of calcium chloride by cement weight and an electric current $\left(100 \mu \mathrm{A} / \mathrm{cm}^{2}\right)$ was applied to reinforcement in order to accelerate corrosion and consequently make quickly corrosion-induced-cracking. Rebar diameter loss was estimated using weight loss measurements. The results obtained allowed finding a linear trend between crack width and corrosion penetration (pits depth) for several concrete cover to rebar diameter ratios $(\mathrm{c} / \varphi)$ and several water to cement ratios.

Vidal et al. (2004) used the same approach on mechanically loaded reinforced concrete beams. In this study, thirty-six reinforced concrete beams were cast in 1984 to study the influence of corrosion on mechanical properties. Those beams were stored continuously under loading to evaluate the impact of mechanical loading on corrosion initiation and development. To accelerate corrosion, all the beams were 
kept in saline environment. A saline fog (35 g/l of sodium chloride corresponding to the salt concentration of sea water) was created by means of sprays. In addition, they were submitted to wetting and drying cycles that is to say an artificial environment simulating marine conditions. Beams A and B were examined after seventeen and fourteen years of storage respectively. Beams A and B were cast with different reinforcement diameters (Figure 2) but the same steel (yield strength around $500 \mathrm{MPa}$ ) and different covers respectively 40 and $10 \mathrm{~mm}$. A 13,5 kN.m loading value was applied to the beams (Figure 2).

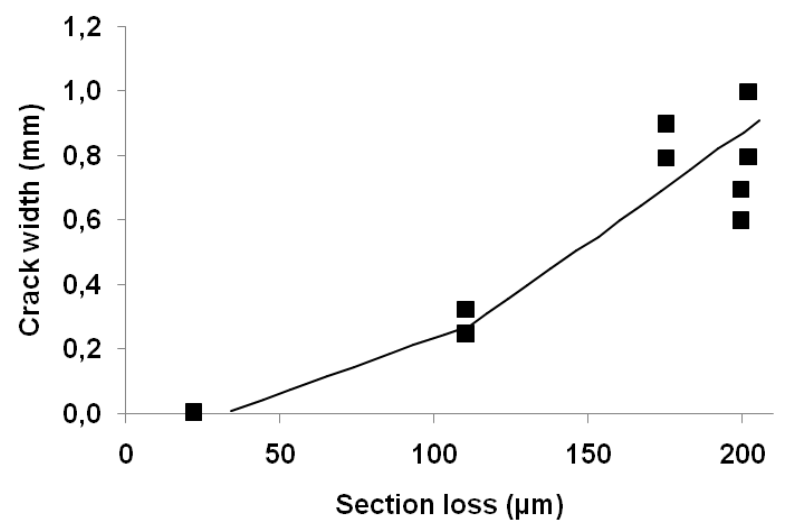

Figure 1. Evolution of crack width versus section loss, from El Maaddawy et al. (2003)

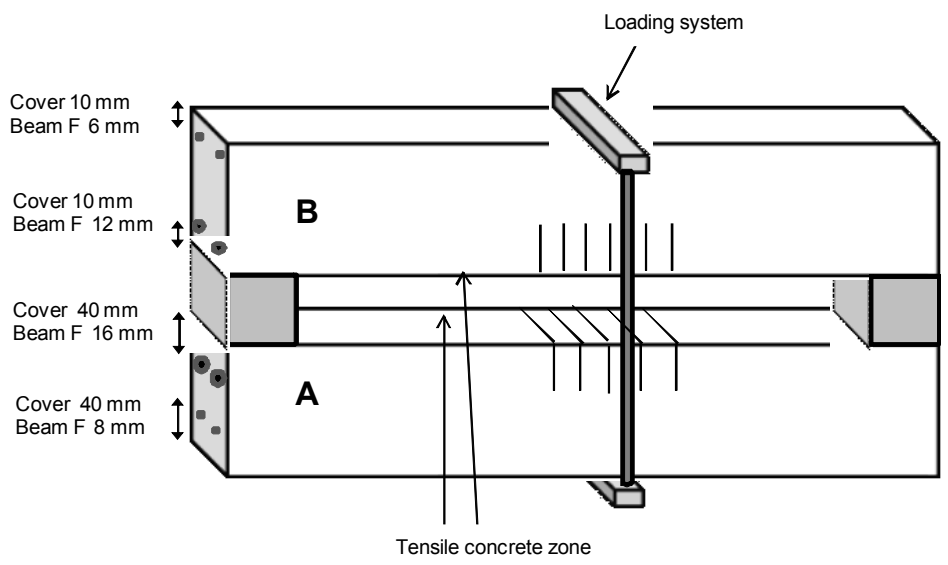

Figure 2. Scheme of the mechanical loading system of $A$ and B Beams, from Vidal et al. (2004) 
In order to study the corrosion propagation, the authors measured the width of the longitudinal cracks caused by rebar corrosion. The reinforcement corrosion state was characterized using section loss measurements. The authors tried to link the crack widths $(\mathrm{w})$ to the section losses $\left(\triangle \mathrm{AS}-\triangle \mathrm{AS}_{0}\right)$ during the propagation of the corrosion. The section loss $\Delta \mathrm{AS}_{0}$ corresponds to the local section loss which is necessary for cracking initiation (Vidal et al., 2004). The results are presented on Figure 3; one can clearly see a linear trend between crack width (w) and section loss $\left(\Delta \mathrm{AS}-\Delta \mathrm{AS}_{0}\right)$.

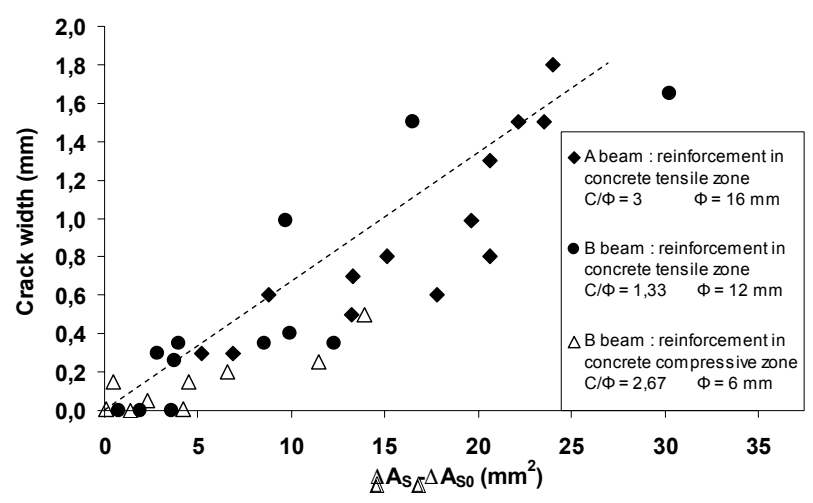

Figure 3. Crack width evolution (w) versus section loss $\left(\triangle A S-\triangle A S_{0}\right)$, from Vidal et al. (2004)

El Maaddawy et al. (2003), Alonso et al. (1998), by imposing a current to the reinforcement and Vidal et al. (2004) by corroding reinforcements with a simulated marine environment showed a link between the crack width and the reinforcement section loss. However, these results were obtained with very controlled environmental conditions. But in a real marine environment, these conditions are not constant and can modify the corrosion behaviour of reinforced concrete structures such as, for instance, the degradation of concrete by sea water and the influence of moisture content in concrete. Thus no experiment tried to link the visual parameters of corrosion to the rebar corrosion state for reinforced concrete structures exposed to a real marine environment. Moreover only crack widths were considered as visual parameters in previous studies. As rust stains areas as well as cracks lengths could inform of the corrosion level of reinforcement, they will be include in the present study complementary to cracks widths measurements.

The aim of the present paper is to establish relations between visual signs of corrosion and corrosion state for forty years old reinforced concrete beams stored in a real marine environment. These beams were characterized during the French project: "Benchmark des poutres de la Rance" (2004-2005) (L'Hostis, 2007; L'Hostis et al., 2006). These beams were submitted to natural chloride-inducedcorrosion. They will be used to verify the applicability of Alonso et al. (1998) and Vidal et al. (2004) approaches in these conditions. 


\section{Description of specimens considered for the study}

Between 2004 and 2005, twenty reinforced concrete beams were characterized in term of physico-chemical properties (non-destructive and destructive evaluation of rebars corrosion state) and mechanical behaviour (tensile and flexural tests). These beams have been cast and stored during about 40 years in a tidal marine zone: firstly on a site near Rance's dam (Brittany, France) until 1976, then on IFREMER site in Sainte-Anne de Portzic (Brittany, France) in similar conditions until 2000.

The dimensions of beams were $250 \times 20 \times 20 \mathrm{~cm}$ (Figure 4). The ends are protected by an impervious bituminous binder. Each beam is different from the others and is identified according to three numbers:

- the first number corresponds to the layout configuration (1 to 9). As a matter of fact, concrete was prestressed using post-tensioned wires, placed under a plastic sheath, and anchored at the beam ends. For eight of the beams, the prestressing cables were centred along the beam axis. For twelve other beams, cables were in the lower part of the beam;

- the second number corresponds to the aggregates distribution (continuous $=1$ or discontinuous $=2$ );

- the third number corresponds to the cement content $\left(300 \mathrm{~kg} / \mathrm{m}^{3}\right.$ of cement $=1$ and $400 \mathrm{~kg} / \mathrm{m}^{3}$ of cement $=2$ ).

The cement used is the former French CPAL 210-325. It would correspond to a classical cement CEM II/A with $65 \%$ of clinker and $35 \%$ of secondary constituents (with a percentage of slag about $10-20 \%$ in cement mass). The gravels $(15 / 25 \mathrm{~mm}$ and $5 / 15 \mathrm{~mm})$ and sand $(0 / 5 \mathrm{~mm}$ from Seine River, France) are used as coarse and fine aggregates. Table 1 summarizes the mix proportions of concrete.

Table 1. Concrete mixture proportions

\begin{tabular}{|c|c|c|c|c|c|c|c|}
\hline \multicolumn{2}{|c|}{ Name of the beam } & \multirow{2}{*}{$\begin{array}{c}\text { Total } \\
\text { water } \\
\text { (I) }\end{array}$} & \multirow[b]{2}{*}{$\begin{array}{c}\text { Cement } \\
\mathrm{kg} / \mathrm{m}^{3}\end{array}$} & \multicolumn{3}{|c|}{$\begin{array}{l}\text { Aggregates grading } \\
\left(\mathrm{kg} / \mathrm{m}^{3}\right)\end{array}$} & \multirow[b]{2}{*}{$\mathbf{W} / \mathbf{C}$} \\
\hline Granulometry & $\begin{array}{l}\text { Cement } \\
\text { content }\end{array}$ & & & $\begin{array}{c}\text { Sand } \\
0 / 5\end{array}$ & $\begin{array}{c}\text { Gravel } \\
10 / 25\end{array}$ & $\begin{array}{c}\text { Gravel } \\
5 / 15\end{array}$ & \\
\hline 1 & 1 & 200 to 210 & 300 & 800 & 930 & 320 & 0.67 \\
\hline 1 & 2 & 210 to 220 & 400 & 550 & 930 & 290 & 0.53 \\
\hline 2 & 1 & 220 & 300 & 500 & 1350 & / & 0.73 \\
\hline 2 & 2 & 250 & 400 & 450 & 1350 & 1 & 0.63 \\
\hline
\end{tabular}


The compressive resistance of each formulation (Table 2) was measured using cylinders cast in the same time (using the same batch) (Bertrandy et al., 1980). For each formulation, the two extreme values measured compressive resistances are reported (Table 2).

Table 2. Compressive stress of beams

\begin{tabular}{|c|c|c|}
\hline \multicolumn{2}{|c|}{ Name of the beams } & \multirow{2}{*}{$\begin{array}{c}\text { Compressive stress } \mathbf{R}_{\mathrm{c}} \\
\text { (MPa) } \\
(\mathrm{min}-\mathbf{m a x})\end{array}$} \\
\hline Granulometry & $\begin{array}{l}\text { Cement } \\
\text { content }\end{array}$ & \\
\hline 1 & 1 & $20.5-26$ \\
\hline 1 & 2 & $26.5-33$ \\
\hline 2 & 1 & $13.8-18.7$ \\
\hline 2 & 2 & $13.8-20.5$ \\
\hline
\end{tabular}

Beams were reinforced using plain carbon steel bars $(\varphi 6 \mathrm{~mm})$ and 10 stirrups ( $\varphi 6 \mathrm{~mm}$ ) spaced out about $250 \mathrm{~mm}$ apart. The yield stress was respectively for passive steel and prestressing steel 309 and $1304 \mathrm{MPa}$. Concrete cover thickness of passive reinforcing steels was 16 or $41 \mathrm{~mm}$ depending on layout configurations (Figure 5).
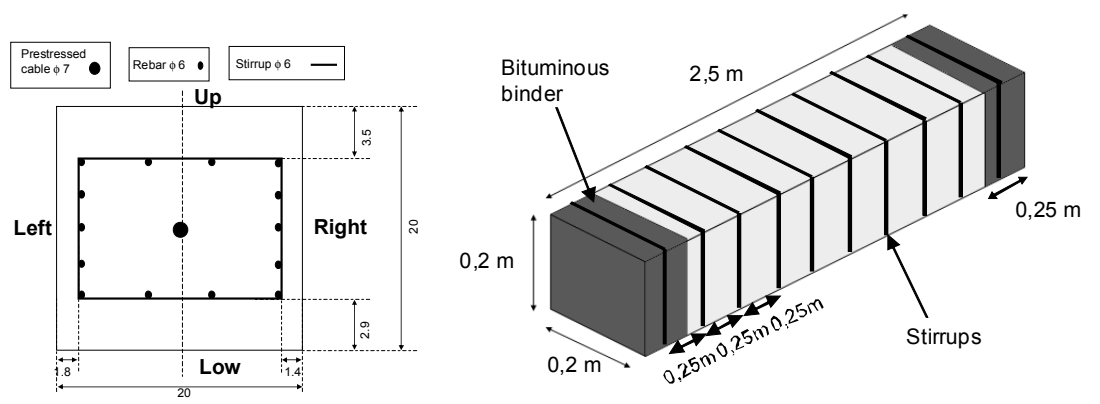

Figure 4. Layout of beams with $X 1=1$, notation of sides, location of prestressed cables and rebars, concrete cover

For each side (low, left, up and right), crack maps were drawn, focusing on locations of longitudinal cracks due to rebars corrosion phenomenon. This precaution allowed to avoid effects of prestress as well as consequences of stirrups corrosion. On these maps, the length and width of each referred crack were also reported. In addition to cracks, rust stains were also recorded (Figure 5). 


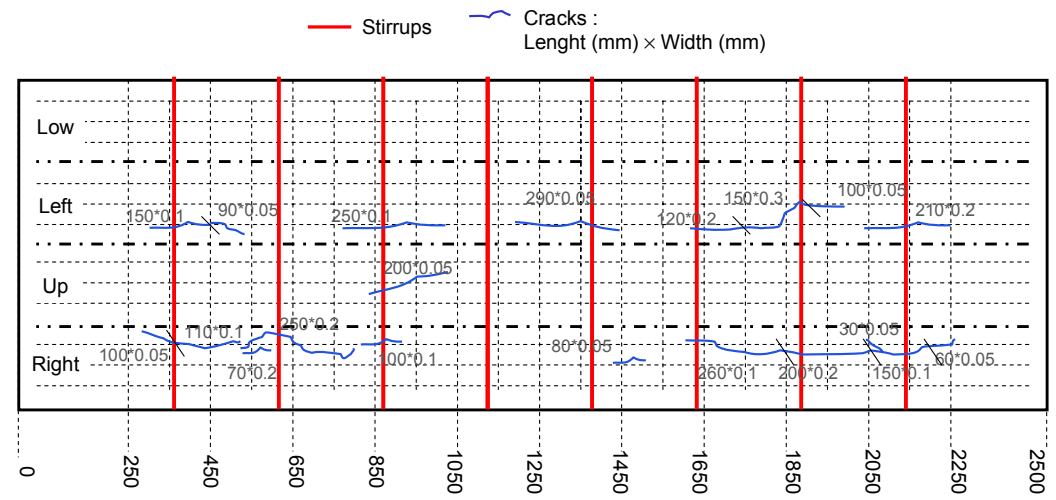

Figure 5. Example of a cracks map drawn from the visual observation

Visual (external) observations can be confronted to the real rebar corrosion state. As a matter of fact, for each rebar (14 rebars for each beam) the section losses have been measured with a vernier calliper all along the reinforcement $(250 \mathrm{~cm}$ long). These corrosion data (section loss measurements, cracks and rust stains maps) were mainly used within the Project "Benchmark des poutres de la Rance" for the validation of service life models.

In a first part, section losses will be related to cracks, in terms of crack width (using the same approach as Vidal et al. (2004) and also crack length. Then the influence of section losses on rust stains observed on concrete face will be studied.

\section{Relation between corrosion and cracking}

\subsection{Crack width}

The approach proposed by Vidal et al. (2004) was used for the Rance beams. For each beam, the crack width value is reported versus the maximal section loss (expressed in $\mathrm{mm}^{2}$ ). Two examples are presented on the Figure 6 (beams 611 and 421) One can see that there is no clear correlation between these two parameters. This differs from the observations made by Vidal et al. (2004). Two main reasons can be invoked to explain this difference. The first relies on the fact that beams used by Vidal et al. were mechanically loaded. Thus the mechanical loading may increase the transversal crack and finally increases the rebar corrosion. The second aspect which must be considered is that the beams used by Vidal et al. (2004) were kept in an atmospheric environment, whereas the Rance beams were partially immersed in the tidal zone. The water saturated conditions could promote the formation of soluble iron oxides that don't lead to concrete cracking (Broomfield, 2007). 


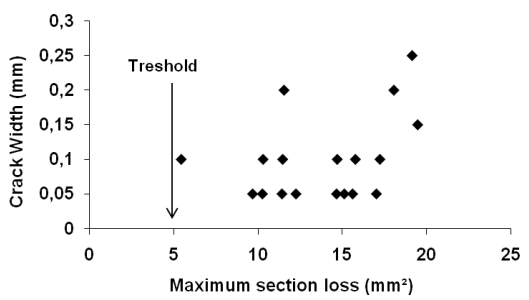

a)

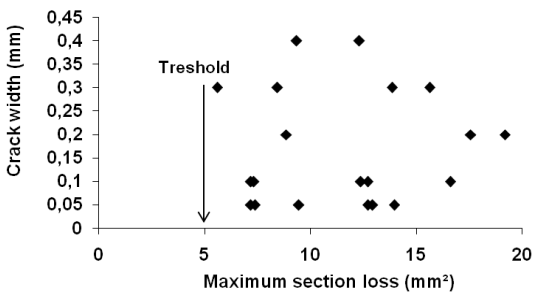

b)

Figure 6. Maximal section losses versus cracks width for: a) beam 611; b) beam 421

\subsection{Crack length}

For this local approach, two methodologies can be used to account for the section loss related to concrete cracking. The first possibility (methodology 1) consists in considering corroded zones (pits) registered immediately behind concrete cracks (Figure 7a), as their location is known from the destructive characterization of the beams. When a corroded area spreads beyond the crack, then all section losses of this corroded area are taken into account. The second one (methodology 2) simulates a non destructive assessment of corrosion (in an existing structure) by considering a zone of cracked concrete, and taking into account all section losses recorded in this zone, directly behind the crack or not (Figure 7b). The methodology 2 consists of using a selection window which takes into account the crack and all reinforcements. In this selection window, all section losses are taken into account.

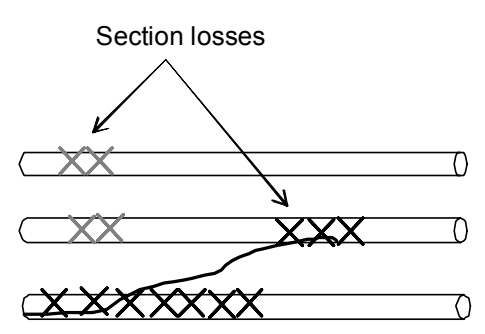

(a)

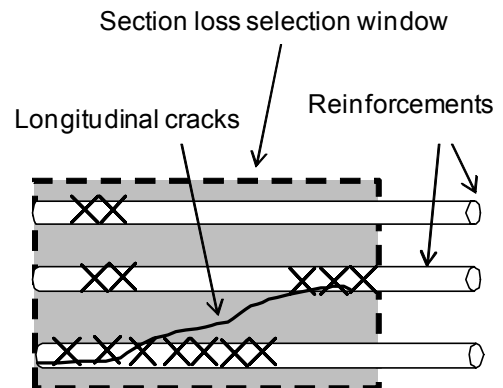

(b)

Figure 7. Methodologies for studying section loss and cracks: a) only corroded areas behind the crack are considered (on the scheme, the black cross corresponds to a selected section loss and the grey cross to a section loss not selected); b) all corroded zones are recorded in a specific concrete zone 


\subsubsection{Methodology 1}

The Figure 8 depicts the crack length evolution as a function of the average section loss calculated from corroded zones recorded behind each concrete crack (according to the methodology 1). No correlation can be deduced from this graph. However, average section losses are mainly $20 \%$ to $30 \%$ in front of cracked zones. Finally, a critical section loss (threshold) leading to crack initiation can be pointed out at around $15 \%$ from the graph.

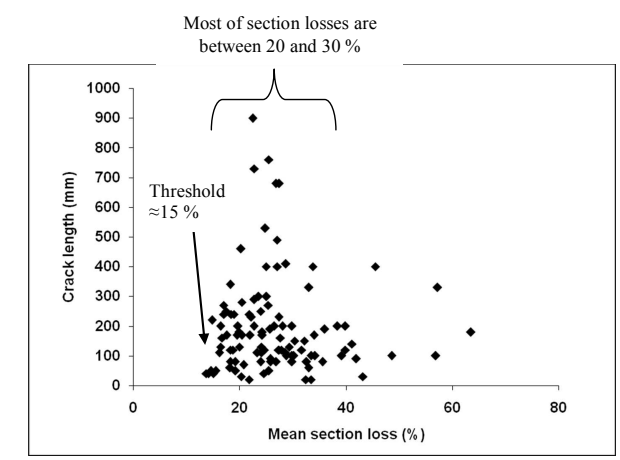

Figure 8. Crack length in function of average section loss (all beams are considered, methodology 1)

\subsubsection{Methodology 2}

Results obtained using the methodology 2 are presented Figure 9. One can see that, for two beams of the corpus; the more the crack length, the less the section loss. This illustrates the fact the width of the selection window increases with crack length; this results in the increase of the non-corroded area. By way of consequence, using this methodology the maximal or critical section loss cannot be underlined. This methodology cannot inform about the level of corrosion behind cracks.

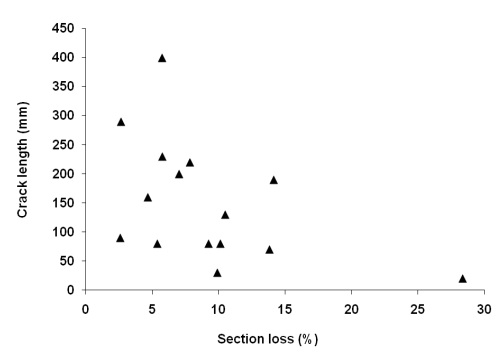

a)

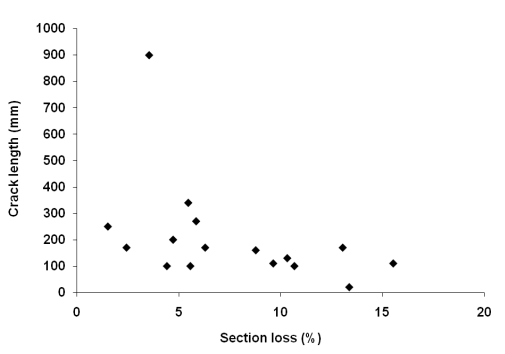

b)

Figure 9. Crack length versus section losses (from methodology 2): a) beam 211; b) beam (412) 


\section{Relation between corrosion and rust stains}

In the Rance corpus, only $50 \%$ of the rust stains could be linked to cracks. The other $50 \%$ appear on sound parts of concrete. For each beam, the number of rust stains increases with the number of cracks recorded of the concrete surface (Figure 10).

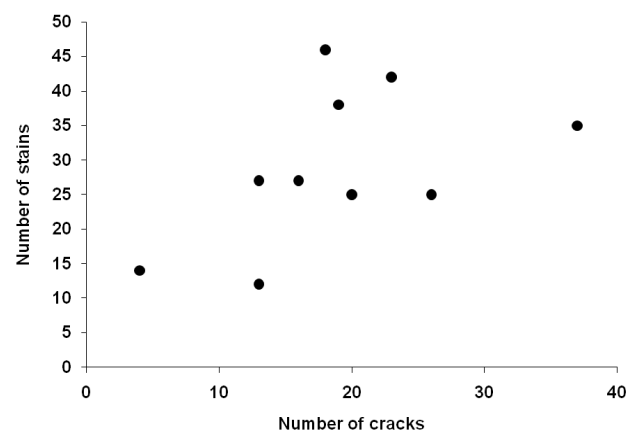

Figure 10. Number of rust stains noted for each beam versus number of cracks recorded on this beam

As rust stains are due to rust transport from corroded rebar within concrete and oxidation at the surface (green rust oxidized into magnetite, Raharinaivo et al. (1987), a correlation between concrete cover thickness and number of rust stains can be expected. One can see on Figure 11 that the larger the concrete cover, the less the number of rust stains. Afterwards, for concrete covers superior to four centimetres, reinforcements are not practically corroded. Since the appearance of rust stains on the concrete facing is linked to the corrosion level of reinforcement, the stain area is very small.

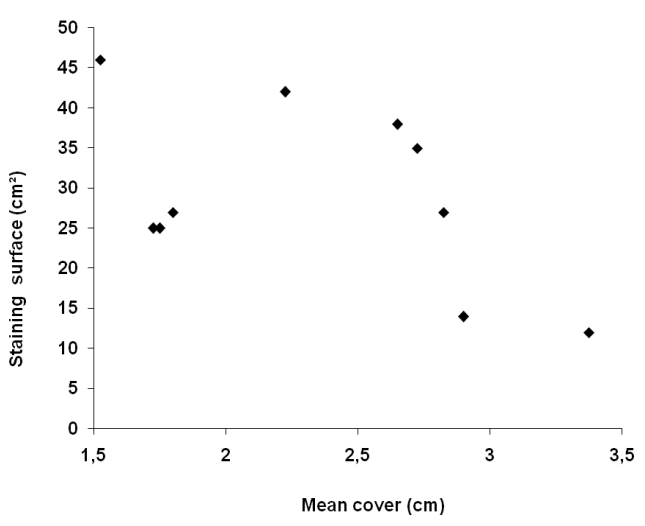

Figure 11. Number of rust stains recorded on concrete facing versus their concrete cover 
The next step consists in correlating the rust stain surface with the average measured section loss. For this purpose, the methodology 1 is used (the section losses are taken into account only when they are immediately behind rust stains). The indicator "rust stain surface" is defined by the surface of the rectangle containing the rust stain (Figure 12). In this study, stains linked to cracks are not taken into account. Indeed rust stain surface is then influenced by the crack. Corrosion products are transported through the crack to the concrete facing. Thus the corrosion level of reinforcement behind crack is not linked to a rust stain.

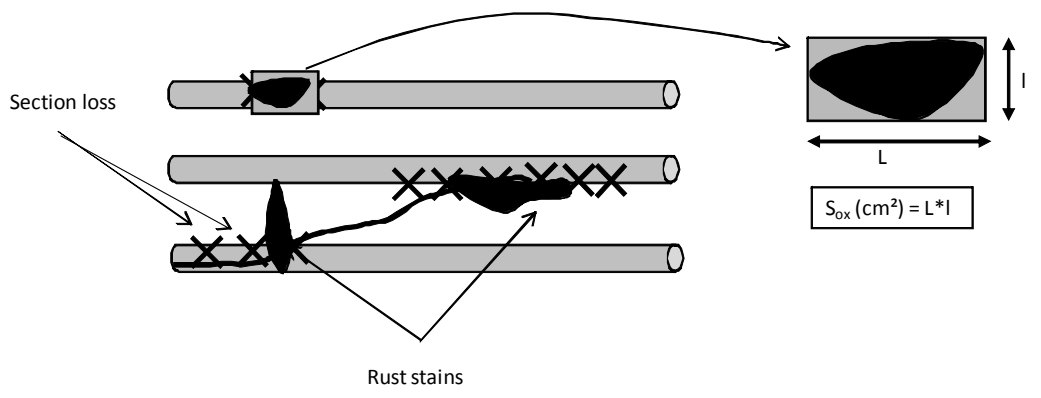

Figure 12. Definition of rust stain surface indicator

Figure 13 presents the evolution of the rust stain surface versus section loss. This graph illustrates that globally, rust stain surfaces increase with corrosion level (section loss). Most of the section losses recorded behind rust stains are between 20 and $30 \%$. Moreover, the graph points out that numerous rust stains are not linked to section losses (section losses equal to $0 \%$ ).

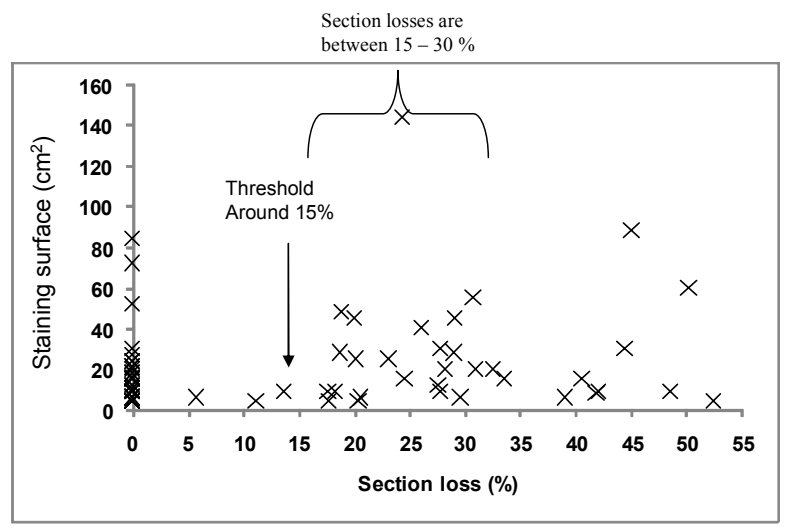

Figure 13. Staining surface versus section loss 
Concrete is made up of a porous cementitious matrix. The pores of the matrix are connected each other, and can be filled with water. When concrete is drying, water is transported via the connected network of pores to the concrete surface (BaroghelBouny, 2007). Then, corrosion products soluble in water could be transported via the connected network of pores in concrete (Figure 14). Thus, corrosion products are not always transported normally (according to the reinforcement) from rebar to the concrete facing.

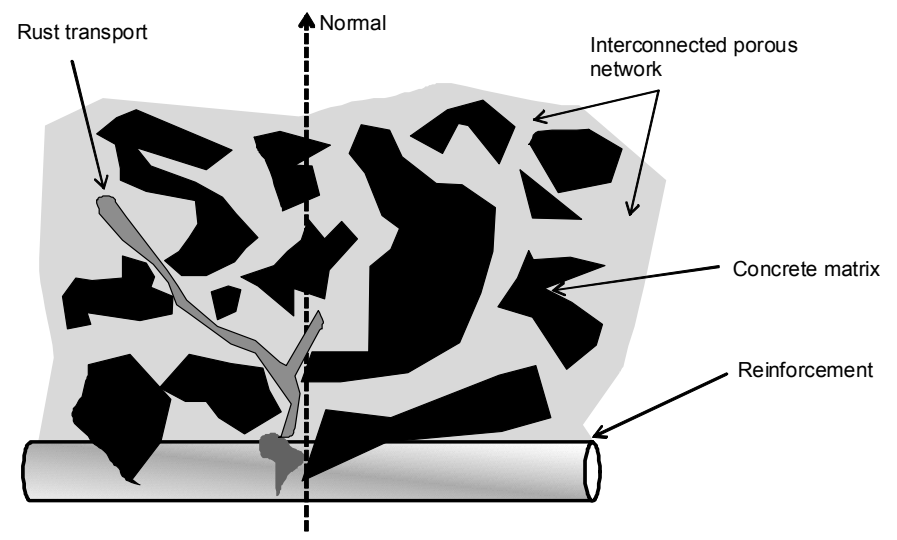

Figure 14. Schematic representation of rust transport inside concrete

\section{Integrated approach for cracks, rust stains and section losses}

The second step of the study aims at looking for links between each crack and the related section losses that can be recorded in front of the considered crack ( 2172 cracks for the entire corpus). For this purpose, distribution of section losses (sorted by tenth of percents) is reported for several conditions (Figure 15):

Considering all the measurements from all the beams (2 172 values), $70 \%$ of the section losses are lower than 30\% (Figure 15a).

Section losses recorded behind cracks (827 values) present almost the same distribution than the previous one: $70 \%$ of the section losses are lower than $30 \%$. Only $8 \%$ are higher than $50 \%$ section loss (Figure $15 \mathrm{~b}$ ).

A different result is obtained when considering the section losses linked to rust spots (61 cases). In these conditions, $24 \%$ of the recorded sections losses are higher than $50 \%$ of the initial steel diameter (Figure 15c). Section losses lower than $30 \%$ are only $50 \%$ in this case. It is important to notice that the 61 considered values are rust spots not linked to cracks. This result indicates that rust spots are only a good indicator for corrosion diagnosis on the "Rance" beams when there are high corrosion levels. 
Regarding undamaged concrete (1 284 values), section losses lower than $30 \%$ represents $70 \%$ of the values, whereas section losses higher than $50 \%$ represents $8 \%$ on values (Figure 15d). This distribution is almost the same as the distribution reported for the cracks zones. This fact can be linked to environmental conditions: as proposed by Sagoe-Crentsil et al. (1993), the green rust formed at the steel concrete interface could be quickly transported and leached by seawater, so that no sign of corrosion is visible on concrete surface. Moreover cracks might appear inside concrete without any detection on the facing of concrete. Those cracks could entail uncertainty on the crack length measurements (Figure 16). This corrosion pattern was shown by Torrres-Acosta et al. (2004).

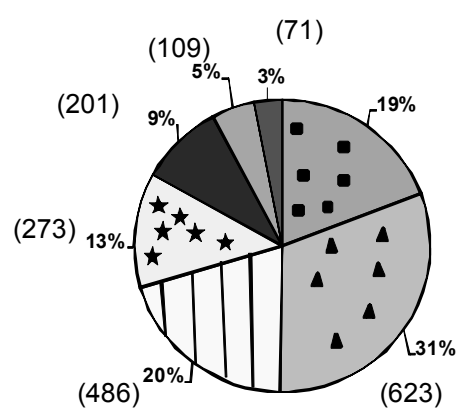

a) all beams

(8)

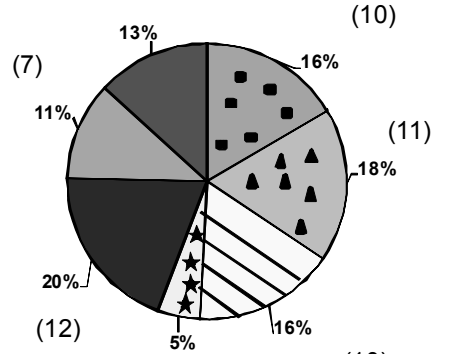

(3)

(10)

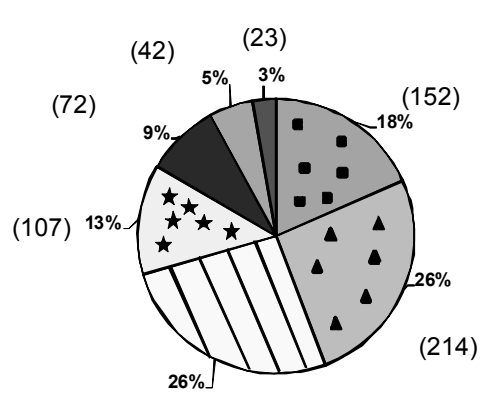

(217)

b) behind cracks

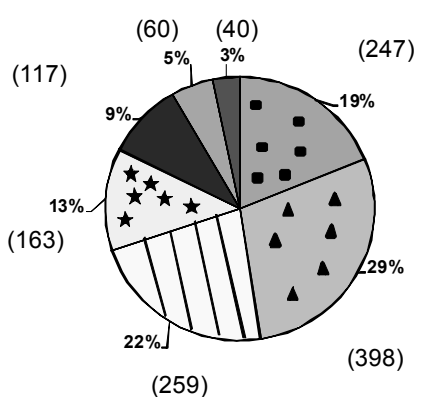

d) behind undamaged concrete
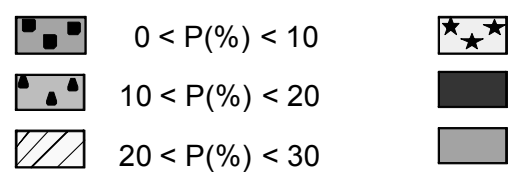

$30<\mathrm{P}(\%)<40$

$40<\mathrm{P}(\%)<50$

$50<\mathrm{P}(\%)<60$

Figure 15. Distribution of section losses a) for all beams; b) for zones placed under cracks; c) for zones under rust spots; d) for zones under undamaged concrete (no crack, no rust stain) 


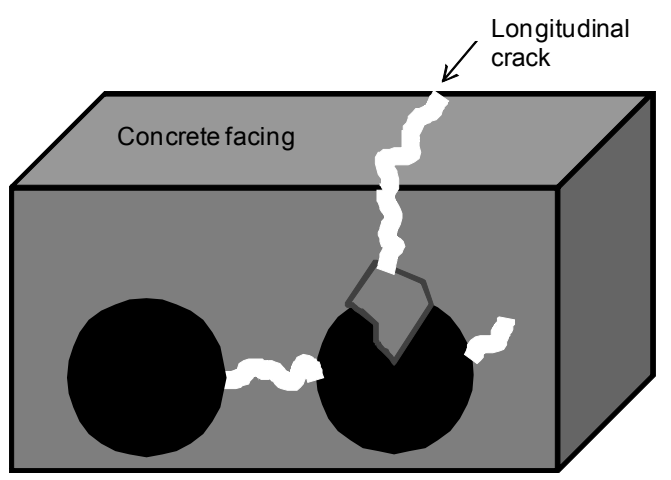

Figure 16. Sketch for crack pattern of a damaged reinforced concrete

\section{Conclusions}

This study aimed at checking if visual signs of corrosion could be linked to the real corrosion state of forty year old beams stored in marine environment ("Rance" beams). The great advantage of this large corpus is that cracks and rust stains maps had been previously drawn and the real steel corrosion state has been assessed thanks to section loss measurements (L'Hostis, 2007). Previous studies from Alonso et al. (1998) and Vidal et al. (2004) were taken as references for the correlation between crack width and corrosion level (section loss).

Results show that the approach proposed by Vidal et al. (2004) is not applicable for the Rance beams, as no linear relation has been found between crack width and corrosion level. Following this observation, additional corrosion indicators were studied. Presence and size of cracks cannot be easily linked to the corrosion state. This can be due to the chloride-induced-corrosion process occurring in water saturated environment that leads mainly to soluble rust ("green rust"). This non expansive corrosion product does not induce mechanical stress within concrete. In addition, cracks inside concrete might appear without possible visual detection. As a consequence, rust stains recorded on the concrete surface appears to be a good indicator of corrosion but only for high corrosion levels. These stains are due to the transport of the green - soluble - rust within concrete and oxidation at the concrete facing. This phenomenon could appear after the sampling and the storage of the Rance beams. Concrete drying has allowed oxygen to transform corrosion products into these rust stains. But there are lots of section losses, which can not be linked to rust stains. This fact might be also caused by a leaching of the beams (for instance, with rainwater or sea water with the tide) during storage. In this context, a prospective study consists in studying the coupling between concrete drying and rebars corrosion on the case of the Rance beams (Charles et al., 2009). The study of visual signs of corrosion such rust stains and longitudinal cracks shows, in case of Rance corpus, reinforced concrete structures which were sea water saturated, that 
there are many locations were no crack and no stain on concrete is identified whereas section losses were measured on the reinforcements. Thereby in case of Rance corpus, visual parameters of corrosion cannot be the only technique to evaluate the level of reinforcement corrosion. But it must be used with additional techniques such as resistivity, potential and corrosion rate measurements.

\section{Aknowledgements}

The authors would like to thank Olivier Poupard who collected all experimental data used in this study (crack and rust stains maps as well as section losses measurements). This study has been financially supported by the Commissariat à l'Energie atomique, Electricite de France (within the CIMETAL research program) and by the National Research Agency (France) under the APPLET research program (grant ANR-06-RGCU-001-01).

\section{References}

Alonso C., Andrade C., Rodriguez J., Diez J.M., "Factors controlling cracking of concrete affected by reinforcement corrosion", Materials and Structures, vol. 31, n 211, 1998, p. 435-441.

Baroghel-Bouny V., "Water vapour sorption experiments on hardened cementitious materials - Part I: Essential tool for analysis of hygral behaviour and its relation to pore structure", Cement and Concrete Research, vol. 37, n 3, 2007, p. 414-437.

Bertrandy R., Vincens A., "Behaviour of reinforced and prestressed concrete structures in the marine environment. An experience which started 18 years ago", Proceedings of the International Symposium on Behaviour of Offshore Concrete AFPC-ARBEM (Publication CNEXO), Brest, France, October 8-10, 1980.

Broomfield J.P., Corrosion of Steel in Concrete - Understanding, Investigation and Repair (second edition), Taylor and Francis Ltd, London, UK, 2007.

Charles S., L'Hostis V., Poyet S., "Impact of moisture parameters on the chloride induced corrosion in concrete", Proceedings of the RILEM Workshop on Long-Term Performance of Cementitious Barriers and Reinforced Concrete in Nuclear Power Plants and Waste Management, RILEM PRO 64, 2009.

El Maaddawy T.A., Soudki K.A., "Effectiveness of impressed current technique to simulate corrosion of steel reinforcement in concrete", Journal of Materials in Civil Engineering, vol. $15, \mathrm{n}^{\circ} 1,2003$, p. 41-47.

L'Hostis V., (sous la direction de), «Benchmark des poutres de la Rance - Diagnostic et modélisation mécanique des poutres en béton armé et précontraint atteintes par la corrosion des aciers », European Journal of Environmental and Civil Engineering, vol. $11, \mathrm{n}^{\circ} 1-2,2007$. 
L'Hostis V., Brunet C., Poupard O., Petre-Lazar I., Validation of mechanical models for reinforced concrete structures: Presentation of the French project "Benchmark des Poutres de la Rance", Journal de Physique, vol. 4, n 136, 2006, p. 273-284.

L'Hostis V., Neff D., Bellot-Gurlet L., Dillmann P., "Characterization of long-term corrosion of rebars embedded in concretes sampled on French Historical Buildings aged from 50 to 80 years", Materials and Corrosion, vol. 60, n 2, 2009, p. 93-98.

Poupard O., L'Hostis V., Catinaud S., Petre-Lazar I., "Corrosion damage diagnosis of a reinforced concrete beam after 40 years natural exposure in marine environment", Cement and Concrete Research, vol. 36, $\mathrm{n}^{\circ} 3$, 2006, p. 504-520.

Raharinaivo A., Genin J.M., "Sobre la corrosión de armaduras de hormigón en presencia de cloruros", Materiales de Construcción, vol. 36, n 204, 1987, p. 5-16.

Sagoe-Crentsil K.K., Glasser F.P., " 'Green rust', iron solubility and the role of chloride in the corrosion of steel at high pH", Cement and Concrete Research, vol. 23, n 4, 1993, p. 785-791.

Torres-Acosta A.A., Sagüés A.A., "Concrete cracking by localized steel corrosion Geometric effects", American Concrete Institute Materials Journal, vol. 101, n 6, 2004, p. 501-507.

Tuuti K., Corrosion of steel in concrete, Ph.D. Thesis, Cement and Concrete Research Institute Stochkolm, Sweden, 1982.

Vidal T., Castel A., François R., "Analyzing crack width to predict corrosion in reinforced concrete", Cement and Concrete Research, vol. 34, n 1, 2004, p. 165-174.

Received: 28 October 2009

Accepted: 11 May 2010 